\author{
Aleksandra Matulewska \\ Adam Mickiewicz University in Poznań \\ Poland \\ e-mail: aleksmat@amu.edu.pl \\ ORCID: 0000-0002-2045-5972

\section{Marek Mikołajczyk} \\ Adam Mickiewicz University in Poznań \\ Poland \\ e-mail: marmikol@konto.pl \\ ORCID: 0000-0003-3991-9340
}

\title{
WHO IS RIGHT, WHO IS WRONG? INTERPRETING 14 POINTS OF WILSON - A CASE STUDY OF DEONTIC MODALS AND THEIR MEANINGS ${ }^{1}$
}

\begin{abstract}
The document titled " 14 points of Wilson" was announced by the President of the United States Woodrow Wilson in his speech addressed to the United States Congress on $8^{\text {th }}$ January 1918. The speech is one of the most well known documents of the First World War as it touched upon several world issues. The text has been interpreted ever since in respect to the importance and real meaning of points formulated by Wilson. One of the points referred to Poland. The aim of the paper is to focus on the exponents of deontic modality used in that text of historical value and to find the answer to the question concerning the deontic value of each point. The analysis will encompass the principles of deontic logic as well as the meaning of deontic modals in legal discourse at the time of speech delivery as those 14 points should be classified as a text belonging to legal genres. The aim of the paper is to present the historical background and the linguistic analysis in order to find out whether historical facts, interpretations and language used correspond with one another.

Keywords: deontic modals, 14 points of Wilson, legal translation, legal interpretation, semiotic analysis of legal text meanings.
\end{abstract}

\section{Introduction}

The main aim of the paper is to analyse the document titled "14 points of Wilson" which was announced by the President of the United States Woodrow Wilson in his speech addressed to the United States Congress on 8th January 1918. The speech is one of the most well-known documents 
of the First World War as it touched upon several world issues. The speech was pivotal as it focused on the vision of American politicians concerning the world after the First World War. It contained the strategies that were to help achieve the world peace. Therefore, the text has been interpreted ever since in respect to the importance and real meaning of points formulated by Wilson. The points referred to territorial issues in Europe. Among others one of them focused on Poland which at that time was not present at the maps of Europe as it was partitioned by Prussia, Austria and Russia. They also contained signposts for foreign postwar American diplomacy that were obviously rated as extremely significant by historians (cf. Kissinger 1996) and there is no denying the fact that the USA implemented the strategy in the early 20th century. The points were also of huge significance as they marked the moment when the USA decided to get fully involved in the conflict which tipped the scales towards Entente. The aim of the paper is to focus on the exponents of deontic modality used in that text of historical value and to find the answer to the question concerning the deontic value of each point. The analysis will encompass the principles of deontic logic (cf. von Wright 1951) as well as the meaning of deontic modals in legal discourse at the time of speech delivery as those 14 points should be classified as a text belonging to legal genres. The aim of the paper is to present the historical background and the linguistic analysis in order to find out whether historical facts, interpretations and language used correspond with one another. The history of the English language and possible variations in meaning of modal verbs under scrutiny in British and American variants in a diachronic perspective have been taken into account (Webster 1928, Mellinkoff 1963, Baugh 1935, 1951, 1957, Stein and Urdang 1966, Hornby 1948, Hornby et al. 1963, 1974) though no significant differences in usage have been observed. The fact the meanings of modals in official and legal contexts have not been observed proves the thesis that the language is frozen and tradition-bound (cf. Mellinkoff 1963).

\section{Research methods and material}

The research material is a part of the already-mentioned document announced by the President of the United States Woodrow Wilson in his speech addressed to the United States Congress on 8th January 1918. The analysis involves exponents of deontic modality in the points itself from 1 to 14 with the exclusion of point three which does not contain any 
deontic modal verb, though the utterance is still deontic as far as its meaning is concerned due to the communication-intention bound meanings of all 14 points.

The research methods include (i) the analysis of the source text in the light of pertinent literature in the field of modern history (the approach of historians to the interpretation of 14 points) and (ii) the analysis of the source text in the light of pertinent literature in the field of linguistics (the interpretation of deontic modals and their meanings in English). In general the semiotic analysis is carried out as the conclusions are that the interpretation of 14 points without taking into account a much wider geopolitical context is not possible.

\section{Historical background: Thomas Woodrow Wilson and his 14 points}

The next 28th President of the United States Thomas Woodrow Wilson was born on December 28, 1856 in Staunton, Virginia, to a pastor's family (Link 1968, 1-35). Brought up in a family with strong Presbyterian traditions, he looked at life through the prism of moral precepts that shaped his views, developed his idealism, which meant subordinating material aspirations and material interests to higher, moral, spiritual and ethical purposes from the religion. As President, Wilson was convinced that he was an instrument that fulfilled the divine purpose of repairing the world (Matera and Matera 2007, 103).

After graduating from Princeton University the future president began his scientific career. In 1902 he became the president of Princeton University. After a few years, however, he resigned from this function and became interested in a political career. He started working in the Democratic Party and in 1908 he was taken into account as a candidate for the presidential nomination. Two years later he took part in the New Jersey Governor's election, which he won with a large advantage. He served this function from January 1911 to March 1913 (Link 1968, 239-307). In 1912, his popularity and position in the Democratic Party was so strong that he became the candidate in the presidential election which he won. On March 4, 1913, Wilson was sworn in as the 28th President of the United States of America (Link 1968, 524-528).

The beginning of his first term expired under the sign of internal problems. Foreign policy was in the background. He is often credited with idealism in that field. As Henry Kissinger stresses, the Wilsonian idea of world 
order originated from a belief in a fundamentally peaceful human nature and the belief that democratic nations are, by themselves, peaceful by their nature (Kissinger, 1996, 236). On the other hand, Wilson was able to act very pragmatically and not always in accordance with the principles he proclaimed publicly. He was the head of the United States in a period of great influx of optimism, based on economic dynamism and the accumulation of wealth. On the eve of the war, the United States was the world's largest economic power and an important political force in the world. The sense of economic power in most Americans gave rise to the need for expansion. The president himself, despite repeated assurances that he was against territorial expansion, did not avoid military intervention from the beginning of his rule in order to locate a pro-American leader in Latin American countries and defend American interests (Dobrzycki 1996, 246-249).

In the summer of 1914, the First World War broke out in Europe. It was for Wilson and for most Americans a total and unpleasant surprise (Mamatey 1957, 40). The United States, in the face of this conflict, intended to remain faithful to the principles of isolationism. Even before the outbreak of the war, the president repeatedly pointed to the mission that the "New World" has to fulfill for the sake of the "Old" - European one. Europe from before 1914 was a symbol of degeneration for him. He believed that the future was democracy and the appreciation of smaller states, and therefore also the breakdown of Western powers in the long run. With the outbreak of the war, he was convinced that the goal of the United States should be to show the world a proper signpost on freedom, justice and peace. In a speech he made at the beginning of the conflict on July 4, he spoke about the mediating role of the United States in this conflict. In this speech he also developed the messianic vision of America the Redeemer. From the very beginning of the war he was guided by the idea of developing the world peace (Matera and Matera 2007, 103).

Wilson returned to his mediation proposal addressed to the conflicted parties on December 7, 1914, when he announced the declaration of neutrality. He still believed that the First World War was a conflict that did not concern the United States and therefore they could act as an impartial mediator, reconciling the enemies, introducing peace and a new international order. The vast majority of Americans for whom the war in Europe was the internal problem of inhabitants shared his point of view. Although the Entente countries enjoyed greater support, it should be remembered that in the United States there was also some support for the other side of the conflict, for example expressed by ten million Americans of German descent (Chwalba 2014, 282). 
The mood in America changed, however, when at the beginning of 1915, Germany announced a war zone around the British Isles and threatened to sink the ships of neutral states. Wilson considered this a breach of international treaties. The situation worsened even more when Germany started implementing its plan. On May 7, 1915, a German submarine sank the British passenger ship "RMS Lusitania", which contained 1,200 people, including 128 American citizens (Matera and Matera 2007, 105-106). This event led to a significant increase in anti-German sentiment in the United States. Nevertheless, Wilson proceeded to the next elections in 1916 with assurances that he would keep the United States away from the war. These pacifist slogans secured him victory and rule for the next four years. At the same time, it should be noted that despite the neutrality, until April 1917, the Entente countries received loans and credits of USD 2.5 billion from the United States (Dobrzycki 1996, 250).

In the middle of 1916, only a few hundred American volunteers fought in Europe. However, at the end of the year, the Entente countries exerted more pressure on the United States to join the war. Among others they used the anti-German propaganda that represented the Germans as barbarians. It brought significant success. In the United States, a civic movement was born in defense of democracy and freedom. Wilson was still trying to mediate to bring peace without winning either side. But when on February 1, 1917, Germany announced that they would sink every ship around Great Britain, France and Italy, two days later the president broke off diplomatic relations with Berlin (Mamatey 1957, 52).

The scandal connected with the Zimmermann telegram had a very serious influence on the decision of the American government (Pajewski 1998, 589-591). His author was the secretary of state in the German Ministry of Foreign Affairs. On January 16, 1917, he sent a telegram to the German ambassador in the United States, which was then redirected to a German envoy in Mexico. Zimmermann recommended the diplomat to convince the Mexican authorities to take military action against the United States. This telegram was intercepted by the British intelligence and handed over to the Americans. His publication on March 1 shook the American public opinion and contributed to the further growth of anti-German moods in the country. The Americans finally came to the conclusion that their country could no longer remain neutral and that Germany was a direct threat to their interests.

On April 2, Wilson gave a speech before Congress to recommend declaring war on the German Empire (Wilson 1945, 137). In his "war address", Wilson emphasized American disinterestedness in the war and declared 


\section{Aleksandra Matulewska, Marek Mikołajczyk}

that the purpose of the participation of the United States in the conflict was to destroy the autocratic power, fight for ultimate peace, and in the long run create an international organization working for the preservation of peace (Low and Wilson 1918, 247). The President's proposal was adopted by a large majority and the United States declared war on Germany on April 6. It should be noted, however, that the United States joined the war as an associated state and not as an ally of the Entente. At the end of 1917 the US government declared war against Germany Austro-Hungary.

According to many historians, the US accession to the war in 1917 was significant for the final settlement of the conflict. In the monumental "Diplomacy" by Henry Kissinger, we read that US aid was indispensable for defeating Germany. Similarly, the Polish historian Andrzej Chwalba claims (in his work on the Great War, published in 2014, at the beginning of the chapter devoted to the US participation) that joining the war by the USA was not only a sensation but also the most important event for both parties to the conflict. He also emphasizes the great potential of this country, which counted 100 million inhabitants and generated $30 \%$ of the world's wealth (Chwalba 2014, 282). In the initial period until the end of 1917, however, the effective assistance of the United States to the Entente states was relatively small due to limited military and transport capabilities. The situation has changed the next year. At the end of the war, 10,000 American soldiers were coming to France a day. By autumn 1918, more than 2 million Americans reached Europe (Chwalba 2014, 294). There is no doubt that to a great extent thanks to them, the Entente countries broke the four-year pat on the Western Front.

On January 22, 1917, even before the start of the war, President Wilson in his address to the Senate outlined the proposals for the future international order (Wilson 1945, 128). He wanted to register himself in history as the one who would reconstruct the world order, basing it on noble goals and universal principles. According to his proposition, it was to be the peace between equal nations. It was to be concluded immediately, without any annexations and compensation, respecting the will of nations to self-determination. Treaties ending the war were to be public. He also announced the creation of an international organization after the war, the purpose of which was to supervise the observance of peace and uphold common security and freedom of trade. As Kissinger points out, however, Wilson was not an idealist to believe in the attractiveness of his proposals, and therefore he was ready to support his arguments by exerting pressure (Kissinger, 1996, 239). 
In order to impose the peace on "worse" Europe through the "better", more developed United States, Wilson accepted the creation of the so-called "Inquiry Group" in mid-1917, bringing together about 150 experts representing various fields of international life. There were in this group, among others geographers, economists, historians, specialists in international law. They were entrusted with the preparation of peace plans, assuming the victory of the United States and Entente (Pajewski 1998, 619-620). Each of the group members were perfectly familiar with the outlines of the future peace contained in hundreds of statements issued by the president. The role of the Inquiry Group was to fill the content of these general declarations and give them a specific form. The result of their work was encapsulated in 14 points, which the president presented in his address on January 8, 1918. Their diversity shows the full and integral nature of American proposals. However, it should be noted at the same time that this program did not contain anything new. It can be assumed that the proposals presented in 14 points were in a sense a repetition and clarification of previous loose and occasional statements of the president himself and people from his immediate entourage. Their significance, however, boils down to the fact that they were publicly announced by Wilson himself. Thus, it could be considered as the official war objectives of the United States.

Wilson's peaceful program presented in 14 points was then supplemented and enriched with the announcement of four principles of world peace in 1918 (Wilson 1945, 162) and the presentation of the principles of the future League of Nations (Wilson 1945, 170). This program was based on Wilson's fundamental idea that justice should be the foundation of a future peace deal.

On December 14, 1918, President Woodrow Wilson came to Europe to attend the Paris Peace Conference, which was to establish a new order after the war (MacMillan 2003, 3-16). There he met with representatives of other 26 countries. The Paris conference ended with the signing of the peace treaty with Germany on 28 June 1919 and the adoption of the Covenant of the League of Nations, which was the main interest of the American president. This organization was supposed to guard the new world order he had talked about for years. For his contribution to the founding of the League of Nations, Wilson received the Nobel Peace Prize in 1919. However, the United States Congress refused to ratify the Covenant establishing the League of Nations, which was a personal defeat of the then very ill Wilson. His second term ended in 1920. Four years later he died. 


\section{Deontic modality at the end of $19^{\text {th }}$ and the beginning of $20^{\text {th }}$ century and the interpretation of $14^{2}$ points of wilson - a case study}

The address of President Woodrow Wilson delivered before a joint meeting of Congress on $8^{\text {th }}$ January 1918, known as the Fourteen Points of Wilson or the Fourteen Points speech of Wilson, belongs to the category of formal texts. Therefore, the analysis of that text in the light of its deontic meaning should first of all take into account the interpretation of deontic modals used in it as markers of formal utterances. What is more, the speech was made in 1918, therefore in order to interpret its modal meanings one needs to resort to grammatical rules and semantic interpretation of exponents of deontic modality. As it has already been stated the purpose is to check whether the linguistic analysis of meanings conveyed by exponents of deontic modality will be the same as the conclusions drawn by historians such as Kissinger who points out that the first eight points are goals that must be met, six more are goals that should rather than must be fulfilled (cf. Kissinger, 1996, 239-240 or Pajewski 1998, 622).

The Fourteen Points were very idealistic and general. They outlined a democratic and liberal vision of the world which was hard to achieve as it aimed at weakening colonial powers and changed the balance of powers all around the world. It was the Paris Peace Conference which brought the implementation of Wilson's idealistic vision and it had to be negotiated with leaders of other countries which belonged to the victorious Allied forces. Nevertheless

Wilson's Fourteen Points played an essential role in world politics over the next several years. The speech was translated and distributed to the soldiers and citizens of Germany and Austria-Hungary and contributed to their decision to agree to an armistice in November 1918. (Fourteen Points. November 16, 2009. History.com Editors.).

What is more,

Wilson urged the establishment of an international governing body of united nations for the purpose of guaranteeing political independence and territorial integrity to great and small countries alike. His idea gave birth to the shortlived League of Nations. The more viable United Nations would come into existence only after the conclusion of another devastating global conflict: World War II. (Fourteen Points. November 16, 2009. History.com Editors.).

The Fourteen Points are composed of two parts a sort of introduction and the enumeration of the points. The introduction is not analysed here 
mostly due to the fact that it is a sort of preamble stating the reasons for the formulation of points. Thus it is the justification for the program delineated by the points itself. The enumeration is preceded by the emphatic sentence "The program of the world's peace, therefore, is our program; and that program, the only possible program, all we see it, is this:" in which the noun program is repeated four times to give the text extra emphasis, not to mention other exponents of emphasis such as therefore, our, we, only, and finally all, where our and we refer to the USA as a supreme power.

When discussing the meaning of modals one should refer to Biber's three categories of deontic modal verbs and the exponents of deontic modality in English that is to say: (i) permission/possibility/ability (expressed by the following English modal verbs: can, could, may, might), (ii) obligation/necessity (expressed by the following English modal and auxiliary verbs as well as deontic expressions: must, should, (had) better, have (got) to, need to, ought to, be supposed to), (iii) volition/prediction (expressed by the following English modal verbs: will, would, shall, and expression: be going to) (Biber et al. 1999: 485).

In general deontic mode encompasses acts that are obligatory, forbidden and permitted. As von Wright (1951: 1) claims: "There are the deontic modes or modes of obligation. These are concepts such as the obligatory (that which we ought to do), the permitted (that which we are allowed to do), and the forbidden (that which we must not do)." Though there is also the recommendation which is a sort of weak obligation with negative consequences possibly occurring.

\section{The meaning and interpretation of Points with the modal verb must}

The modal verb must occurs four times in the Points and it expresses categorical obligation. In general the verb occurred in Old English (moste, past tense of motan) and it was probably borrowed from Proto-Germanic motanan. What is more, it has been proven that the past tense form was used "as present tense from c. 1300, from the custom of using past subjunctive as a moderate or polite form of the present." (https://www.etymonline. com/word/must\#etymonline_v_19310). What is important is the fact that must expresses immediate or future obligation, necessity as well as certainty or strong probability (cf. Hornby 1948: 644-645, Hornby et al. 1948). In other sources we find the meaning of being "bound or obliged by an imperative requirement, ... to be under the necessity to, ... to be compelled to, as by the use of threat or force, ... to be forced to, as by convention, 
the requirements of honesty, etc." (Stein and Urdang 1966: 944). Those definitions in fact find confirmation in earlier sources such as "An American Dictionary of the English Language" which was published in 1828 (Webster 1828), which confirms that the language usage in respect to the modal verb must did not change in the period under scrutiny.

When analyzing the grammar course books dated to $19^{\text {th }}$ and early $20^{\text {th }}$ century we discover that must expresses in general obligation. Bain $(1863,108)$ indicates that that modal verb expresses various shades of necessity starting with compulsion and uncontrollable desire, which are not applicable here and ending with 'Certainty, or necessary inference, some thing that we can count on". The verb expresses the obligatory mood in general, that is to say necessity (Bain, 1863, 94; Putnam 1928, 74; Hunter 1848, 65-66). According to Yates $(1973,40)$ "Must signifies a necessity to the performance of the action of the verb, as existing independently of the will of the subject". Kruisinga (1931, 458-462) focuses on the following meanings of must pertinent to this research: (i) necessity, (ii) necessity imposed by circumstances, and (iii) certainty of a fact.

1. Open covenants of peace must be arrived at, after which there will surely be no private international action or rulings of any kind, but diplomacy shall proceed always frankly and in the public view.

5. A free, open-minded, and absolutely impartial adjustment of all colonial claims, based upon a strict observance of the principle that in determining all such questions of sovereignty the interests of the population concerned must have equal weight with the equitable claims of the government whose title is to be determined.

7. Belgium, the whole world will agree, must be evacuated and restored, without any attempt to limit the sovereignty which she enjoys in common with all other free nations. No other single act will serve as this will serve to restore confidence among the nations in the laws which they have themselves set and determined for the government of their relations with one another. Without this healing act the whole structure and validity of international law is forever impaired.

14. A general association of nations must be formed under specific covenants for the purpose of affording mutual guarantees of political independence and territorial integrity to great and small states alike.

In that instance there is no denying the fact that those issues were of utmost importance. Other linguistic markers such as categorical negation in point one 'there will surely be no private international action or rulings' and temporal markers e.g. 'always'; in point five adverbs 'absolutely', ad- 
jectives 'strict', in point seven again negation 'no other single act', temporal marker 'forever' and phrase expressing total support 'the whole world will agree' and finally in point fourteen adjective 'alike' are used to make the obligatory force unquestionable. In the case of points 1, 5, 7 and 14 we deal with necessity, and to be exact necessity imposed by circumstances.

\section{The meaning of the modal verb shall}

The modal verb shall occurs in the Points once and its meaning is open to interpretation. In general language shall no longer carries the meaning of obligation. But in legal and official language it may be used in the obligatory sense (cf. Garner 2001). On the one hand the Points are the idealistic, liberal, democratic vision of Wilson and as a whole constitute the US strategy that should be implemented. But in politics all texts are subject to negotiation and well formulated texts always contain elements that are of paramount importance and secondary importance to open floor for discussion. That is the difference between discourse of democracy and dictatorship. In order to interpret the points containing shall it seems necessary to find out the meaning of the modal at that time. According to the entry from Black's Law Dictionary published in 1910

As used in statutes and similar instruments, this word is generally imperative or mandatory; but it may be construed as merely permissive or directory, (as equivalent to "may,") to carry out the legislative intention and in cases where no right or benefit to any one depends on its being taken in the imperative sense, and where no public or private right is impaired by its interpretation in the other sense. Also, as against the government, "shall" is to be construed as "may," unless a contrary intention is manifest. (Black 1910: 1081)

Analyzing English grammar Hunter (1848, 64-65) claims that shall in persons other than first person singular means obligation. It is an imperative mode which expresses someone's desire that his or her order will be fulfilled. The next author stresses that as far as English grammar is concerned apart from expressing present and future, shall is used to express moral necessity (Maetzner 1874, 82) or imperative mood (Maetzner 1874, 136). Bain $(1863,94)$ stresses that "The legislature uses 'shall' to signify its commands; another form used in common life is 'must'." In general in common speech shall is not considered strong enough to express unconditional obligation. According to Putman $(1928,74)$ in second and third persons both singular and plural shall is a modal verb which 
"promises, commands or threatens". Also Hunter (1848, 64-65) stresses that it is rather imperative. Shall "is used when the source or motive of action is supposed to exist out of the subject; i.e., as a duty or necessity" (Yates 1873, 39). Kruisinga (1931, 463-478) stresses that shall may be used with the weak and strong stresses. The modal verb when used with the weak stress may mean: (i) a promise, warning or threat, (ii) a will or wish of the person addressed, but when used with the strong stress it may mean: "the will of the speaker with regard to somebody else's action, experience, or state" (1931, 464-465). Additionally, it should be remembered that the strong stress meanings are typical for sentences in second and third persons.

Here is point 1 containing the modal verb shall:

1. Open covenants of peace must be arrived at, after which there will surely be no private international action or rulings of any kind, but diplomacy shall proceed always frankly and in the public view.

The meaning of shall in that particular instance seems more the statement of future fact that will follow rather than the obligation itself as in that fragment we deal with cause-effect chain of events: first there must be "open covenants of peace" and once they are implemented there will be two consequences following that is to say "no private international action or rulings of any kind" and diplomacy which "shall proceed always frankly and in the public view." Thus it seems that in that particular instance it is rather the case of formal usage of shall in order to say that something certainly will or must happen as a consequence. Shall in that sense also expresses necessity. That meaning is also found in Webster's Dictionary of American English (1828) where it is pointed out that if shall is used in the second and third persons, it actually "implies a promise, command or determination". Additionally, the usage has been observed that utterances containing shall have the "force of a promise in the person uttering them" as well as the "determination in the speaker", and imply "an authority to enforce the act" (Webster 1828). The USA as a supreme power at that time definitely had some authority to enforce the act as other nations actually accepted 14 Points. The modal shall is used in the third person. It is point 1 which actually opens the list of goals of President Wilson and the United States with regard to the peace and diplomatic actions which are necessary in that respect. Therefore, shall is used with the strong stress and expresses the will of the USA with regard to diplomacy which is a tool in the hands of states necessary to declare wars and negotiate, restore and maintain the peace afterwards. 


\section{The meaning of the modal verb will}

Will in general was used in Old English (forms: willan/wyllan) and it meant 'to wish, desire; be willing' or 'be used to be about'. As we read in the Online Etymological Dictionary "The implication of intention or volition distinguishes it from shall, which expresses or implies obligation or necessity" (https://www.etymonline.com/word/will). In the period in question that modal verb was used to express the future state of affairs and the desire for something to happen in the future. In Webster's dictionary (1828) it is given the force of determining that something should be done and at the same time "implying power to carry the purpose into effect." But Putnam $(1828,74)$ is of a different opinion as he claims that will in second and third person both singular and plural "only foretells", Yates $(1873,40)$ also focuses on "simple futurity" of will similarly as Hunter (1848, 6465) who stresses that it is rather used to merely express future. Maetzner also stresses that will is used to express future or desire that something happens (Maetzner 1874, 83-84, 130). Kruisinga (1931, 481-499) points out that will expresses (i) volition, (ii) iterativity and most importantly (iii) futurity of an action. She distinguishes the weak and strong stressed will. The weak stress will means "a verbal idea in a future time in the second and third persons" (1931, 487). Though the author also distinguishes a very extraordinary use of will which serves the purpose of expressing a command but it is reserved for utterances in the second person $(1931,489)$.

1. Open covenants of peace must be arrived at, after which there will surely be no private international action or rulings of any kind, but diplomacy shall proceed always frankly and in the public view.

As already mentioned when discussing the meaning of shall in point one, the modal verb will expresses the future state of affairs that are to follow as a direct consequence of the condition that must be met.

4. Adequate guarantees given and taken that national armaments will be reduced to the lowest points consistent with domestic safety.

In that instance again we deal with the future state of affairs that are considered necessary to achieve the goal that is to say the long-lasting world peace. Those are "adequate guarantees" that are obligatory and once the countries take on themselves the obligation they will need to keep the promise. One more time it is the instance of the consequence that follows giving and taking "guarantees". 
6. The evacuation of all Russian territory and such a settlement of all questions affecting Russia as will secure the best and freest cooperation of the other nations of the world in obtaining for her an unhampered and unembarrassed opportunity for the independent determination of her own political development and national policy, and assure her of a sincere welcome into the society of free nations under institutions of her own choosing; and, more than a welcome, assistance also of every kind that she may need and may herself desire. The treatment accorded Russia by her sister nations in the months to come will be the acid test of their good will, of their comprehension of her needs as distinguished from their own interests, and of their intelligent and unselfish sympathy.

The first phrase "will secure" expresses the future state of affairs as it is to be determined and adjusted to the aim that the nations want to achieve. The second phrase "will be" also refers to the future state of affairs as it refers to seeing the result of the test and the future is not determined yet as it depends on the actions of Russia which will have the consequences in the form of her treatment by other states.

7. Belgium, the whole world will agree, must be evacuated and restored, without any attempt to limit the sovereignty which she enjoys in common with all other free nations. No other single act will serve as this will serve to restore confidence among the nations in the laws which they have themselves set and determined for the government of their relations with one another. Without this healing act the whole structure and validity of international law is forever impaired.

In that point the phrase "the whole world will agree" is figurative and it is not going to be discussed here. It serves the purpose of adding extra emphasis to the mere statement of fact, not requiring proving. At the same time of course it cannot be read literally as everyone knows that there is no issue that all people in the world would agree unanimously upon. The second and third instances of will usage are emphatic. It is an incantationlike repetition expressing future certainty in respect to the healing force of the act.

\section{The meaning of the modal verb should}

The problem with the interpretation of should is that it may mean merely a recommendation, the strength of which actually depends on the geopolitical situation or it may be used in the sense of obligation which is no longer attached to the common (non-legal) meaning of shall. In general should is used thirteen times and only in points referring to territorial issues 
important for nations and countries in Europe. They refer to the possible change of the borders of countries and giving territories and independence to smaller nations. The nations that were to regain their territories interpreted the points as obligatory whereas those that were to lose rather as a recommendation open to negotiations. At the same time it is a conditional future and if used in the second and third persons should denotes obligation or duty (cf. Webster 1828). Should 3 is considered at that time a periphrastic form of shall denoting a weakened down meaning, a desire (Maetzner 1874, 80-84, 93). Bain $(1863,105)$ clarifies than should may denote the meaning of shall when the decision has been made in the past but it may also denote an implied obligation as it "means duty, obligation, or being under the influence of events." But Putnam $(1828,75)$ stresses that should denotes neither "possibility, liberty, power, will nor obligation. It may rather be said to indicate or declare a thing". According to Kruisinga (1931, 467-478) should does not have identical meanings as shall. Should may express: (i) the obligation or duty which is of moral or social nature, (ii) the occurrence or state of affairs which are highly probable, (iii) the determination or promise of the speaker, (iv) a very weak obligation expressing "an opinion as to the correctness or justice of the observation mentioned in the subordinate clause" (Kruisinga 1931, 474).

8. All French territory should be freed and the invaded portions restored, and the wrong done to France by Prussia in 1871 in the matter of Alsace-Lorraine, which has unsettled the peace of the world for nearly fifty years, should be righted, in order that peace may once more be made secure in the interest of all.

9. A re-adjustment of the frontiers of Italy should be effected along clearly recognizable lines of nationality.

10. The peoples of Austria-Hungary, whose place among the nations we wish to see safeguarded and assured, should be accorded the freest opportunity of autonomous development.

11. Romania, Serbia, and Montenegro should be evacuated; occupied territories restored; Serbia accorded free and secure access to the sea; and the relations of the several Balkan states to one another determined by friendly counsel along historically established lines of allegiance and nationality; and international guarantees of the political and economic independence and territorial integrity of the several Balkan states should be entered into.

12. The Turkish portions of the present Ottoman Empire should be assured a secure sovereignty, but the other nationalities which are now under Turkish rule should be assured an undoubted security of life and an absolutely unmo- 
lested opportunity of autonomous development, and the Dardanelles should be permanently opened as a free passage to the ships and commerce of all nations under international guarantees.

13. An independent Polish state should be erected which should include the territories inhabited by indisputably Polish populations, which should be assured a free and secure access to the sea, and whose political and economic independence and territorial integrity should be guaranteed by international covenant.

As all points from 8 to 13 refer to territorial issues their force in fact depends on the possibility to exert political pressure. If we apply the semiotic analysis to the points, we may draw the following conclusions. At that time France was the most powerful nation out of the enumerated ones due to its colonialism. Thus in the case of point eight it must be assumed that issues referring to France were very important and should expresses an obligation rather than recommendation. The geopolitical situation actually called for solving the problems in France as without it the war could not have been ended. The issues of other countries were important for various reasons but of lesser importance than the French claims. For instance the Polish minority in the USA could not be ignored by Wilson as they were people who would go and vote in presidential elections. Moreover, recommendation may be insistent. It should be reminded here that Wilson strongly believed that the future was democracy and the appreciation of smaller states and that the breakdown of Western powers in the long run would be beneficial for the world. Therefore, in general should, used in points 8-13, means the obligation or duty which is of social and political nature. Additionally, in point 13 an opinion is expressed as to the correctness and justice of the observation mentioned in the subordinate clause which states that the Polish state should be restored.

\section{The meaning of the modal verb may}

The modal verb may in the Old English meant 'to have power, may' (https://www.etymonline.com/word/may\#etymonline_v_12463), that is to say it expressed authority enabling someone to do something, permission and possibility (cf. also Webster 1928). That modal occurs in points two, six and eight. It occurs altogether three times. The authors of English grammars are unanimous that may denotes permission, possibility or liberty of doing something (cf. Hunter 1848, 65; Bain 1963, 107; Putnam 1828, 73-74; Yates 1873, 40; Kruisinga 1931, 448-558). Maetzner (1874, 130) points out that may used to be a stronger modal verb but lost its meaning of 'having power' to 'being permitted or inclined' or 'able to'. 
2. Absolute freedom of navigation upon the seas, outside territorial waters, alike in peace and in war, except as the seas may be closed in whole or in part by international action for the enforcement of international covenants.

The first instance is the permission granted to an international body to limit the freedom of navigation. As it has already been stated one of the points referred to the establishment of an international authority. That point was implemented and the vision of Wilson was successful though short-lasting. It took the form of the so-called League of Nations established in 1920 and dissolved in 1946. After the Second World War the idea of having such an international body emerged again and took the form of the United Nations.

6. The evacuation of all Russian territory and such a settlement of all questions affecting Russia as will secure the best and freest cooperation of the other nations of the world in obtaining for her an unhampered and unembarrassed opportunity for the independent determination of her own political development and national policy, and assure her of a sincere welcome into the society of free nations under institutions of her own choosing; and, more than a welcome, assistance also of every kind that she may need and may herself desire. The treatment accorded Russia by her sister nations in the months to come will be the acid test of their good will, of their comprehension of her needs as distinguished from their own interests, and of their intelligent and unselfish sympathy.

In that fragment of 14 points definitely may is used as a possibility.

8. All French territory should be freed and the invaded portions restored, and the wrong done to France by Prussia in 1871 in the matter of Alsace-Lorraine, which has unsettled the peace of the world for nearly fifty years, should be righted, in order that peace may once more be made secure in the interest of all.

Point eight contains may used in the sense of 'to be able to'. In general it refers to the feasibility of action.

\section{Concluding remarks}

Assessing the address of President Woodrow Wilson delivered before a joint meeting of Congress on $8^{\text {th }}$ January 1918, known as the Fourteen Points of Wilson from the linguistic perspective indicates that in fact the first eight points are goals that must be met, six more are goals that should rather than must be fulfilled, which is consistent with the opinions of 
historians (cf. Kissinger, 1996, 239-240, Pajewski (1998, 622). There is no denying the fact that the interpretation of deontic modals with flexible meanings such as shall in official and legal texts or should must take into account a wider semiotic context which involves the geopolitical situation in 1918. As there was no guidance on how to implement them, we must confirm that Wilson's program was based on principles and his idealism, not on authority, law, and interests. It was thus completely different from what the European powers had so far proclaimed (Kissinger 1996, 239-240).

The only two modals which are not open to interpretation are must and may. Their usages are consistent and coherent. They are used in their normal senses overlapping in meaning with legal ones. Therefore must expresses obligation and necessity, including necessity imposed by circumstances, whereas may expresses ability and feasibility of actions.

Though, shall may denote obligation, the semiotic perspective rather indicates that it is used in other sense. It is more a recommendation, moral obligation, a promise or a desired state of affairs. It is definitely, more a promise or a wish that a command. Moreover, the fact that the repetition is not a stylistic issue in that type of genre, and the rule of applying one sign for one meaning consistent with legislative techniques and specialized discourse, repeating must to express the obligatory nature of points would result in generating an incantation like effect that would make them more emphatic and categoric. That stylistic device was used when e.g. repeating the noun program. Therefore, the fact that shall is used only once in the points suggests that its meaning differs from must. It expresses the will of the USA as a supreme power of that period to have something achieved.

Will is used to denote futurity or in other words the future state of affairs that is desired and should follow, especially as a consequence of undertaken actions.

Should definitely refers to the conditional obligation stemming from social and political reasons. It was much better from the perspective of the US President to maintain the balance of powers in Europe. From that perspective it was much better to have several smaller countries established. That solution enabled to diminish the territories of some states in Europe and limit the influence and potential of some military powers of that period. At the same time, the order of points and the usage of modals in them divided them into non-negotiable issues and negotiable issues. The hierarchy of priorities is clearly visible when we analyse linguistic markers of deontic meanings. The strong belief of Wilson that smaller states are necessary to balance the powers in Europe supports that thesis. 
To sum up, the flexibility of meanings of some modals enables translators and historians to tip the interpretation scales towards the meaning which supports their worldview, preferences and goals they want to achieve. Nevertheless, when interpreting the 14 Points one needs to take into account not only opinions but also facts and linguistics which create a much wider semiotic context.

\section{N O T E S}

1 The part titled "Historical Background: Thomas Woodrow Wilson and His 14 Points" was written by Marek Mikołajczyk, the rest of the paper by Aleksandra Matulewska.

2 Point 3 is not discussed here as it does not contain a modal verb. It states that the program presented by Wilson involves: "3. The removal, so far as possible, of all economic barriers and the establishment of an equality of trade conditions among all the nations consenting to the peace and associating themselves for its maintenance." Nevertheless it is obligatory.

3 Apart from being the past form of shall which is of no interest here.

\section{R E F E R E N C E S}

Bain, Alexander. 1863. An English Grammar. London: Longman, Green, Longman, Roberts, and Green.

Baugh, A. C. 1935. A History of the English Language. New York: D. AppletonCentury Company, Inc.

Baugh, A. C. 1951. A History of the English Language. New York: Routledge.

Baugh, A. C. 1957. A History of the English Language. New York: AppletonCentury-Crofts Inc.

Biber D., Johansson S., Leech G., Conrad S. and E. Finegan. 1999. Longman Grammar of Spoken and Written English. Essex: Pearson Education Ltd.

Black, H. C. 1910. Black's Law Dictionary. $2^{\text {nd }}$ edition. https://archive.org/details/ BlacksLawDictionary-Editions1-9/page/n15 (Retrieved on 15 May 2019).

Chwalba, A. 2014. Samobójstwo Europy. Wielka wojna 1914-1918. Kraków: Wydawnictwo Literackie.

Dobrzycki, W. 1996. Historia stosunków międzynarodowych w czasach nowożytnych 1815-1945. Warszawa: Wydawnictwo Naukowe Scholar.

Etymonline - Online Etymological Dictionary. https://www.etymonline.com/word/ must\#etymonline_v_19310 (Retrieved on 15 May 2019).

Fourteen Points. November 16, 2009. History.com Editors. Publisher: A\&E Television Networks https://www.history.com/this-day-in-history/wilson-deliversfourteen-points-speech (Retrieved on 3 March 2019). 
Garner B. A. (ed.) 2001. A Dictionary of Modern Legal Usage. London - New York: Oxford University Press.

Hornby A. S., Gatenby E. V. and H. Wakefield. 1948. The Advances Learner's Dictionary of Current English. London: Oxford University Press.

Hornby A. S., Gatenby E. V. and H. Wakefield. 1963. The Advances Learner's Dictionary of Current English. London: Oxford University Press.

Hornby A.S. 1948. Oxford Advanced Learner's Dictionary of Current English. Oxford: Oxford University Press.

Hornby A.S. with the assistance of A. P. Cowie and J. Windsor Lewis. 1974. Oxford Advanced Learner's Dictionary of Current English. Oxford: Oxford University Press.

Hunter, J. 1848. Text-Book of English Grammar; The Treaties on Etymology and Syntax of the English Language: Including Exercises in Parsing, Punctuation, and the Correction of Improper Diction: An Etymological Vocabulary of Grammatical Terms; and a Copious List of the Principal Works on English Grammar. For the Use of Students in Training Colleges, and the Upper Classes in National and Other Elementary Schools. London: Longman, Brown, Green, And Longmans, Aternoster-Row.

Kissinger, H. 1996. Dyplomacja. Warszawa: Wydawnictwo Philips Wilson.

Kruisinga, E. 1931. Handbook of present-day English. Groningen: P. Noordhoff.

Link, A. S. 1968. Wilson: The Road to the White House. Princeton, New Jersey: Princeton University Press.

Low, A. M. and W. Wilson. 1918. An interpretation. Boston: Little, Brown, and Company.

MacMillan, M. 2003. Paris 1919. Six months that changed the World. New York: Random Mouse Trade Paperbacks Edition.

Maetzner, E. A. F. 1874. An English Grammar: Methodical, Analytical, and Historical with a Treatise on the Orthography, Prosody, Inflections and Numerous Authorities Cited in Order of Historical. Translated from the German, with the Sanction of the Author, by Clair James Grece. London: John Murray. Boston: Roberts, Brothers.

Mamatey, V. S. 1957. The United States and East Central Europe 1914-1918. A Study in Wilsonian Diplomacy and Propaganda. Princeton, New Jersey Princeton: University Press.

Matera, P. and R. Matera. 2007. Stany Zjednoczone i Europa. Stosunki polityczne $i$ gospodarcze 1776-2004. Warszawa: Książka i Wiedza.

Mellinkoff, D. 1963. The Language of the Law. Boston: Little and Brown.

Pajewski, J. 1998. Pierwsza wojna światowa 1914-1918. Warszawa: PWN.

Putnam, J. M. 1828. English Grammar with an Improved Syntax. Part I and II. Concord: J. B. Moore.

Stein, J. (ed.) and L. Urdang (managing ed.). 1967. The Random House Dictionary of the English Language. New York: Random House. 
Who Is Right, Who Is Wrong? Interpreting 14 Points of Wilson...

United States. President (1913-1921: Wilson). 1918. Address of the President of the United States: delivered at a joint session of the two houses of Congress, January 8, 1918. Washington: [Govt. print. off.]. https://babel.hathitrust.org/ cgi/pt?id=mdp.39015074797914 (Retrived on 22 March 2019).

von Wright, G. H. 1951. Deontic Logic. Mind, New Series, Vol. 60, No. 237. (Jan., 1951), pp. 1-15.

Webster, N. 1828. An American Dictionary of the English Language. New York: S. Converse. (also available online at: http://webstersdictionary1828.com/ Retrived on 15 May 2019).

Wilson, W. 1945. Selections for Today. Edited by Arthur Bernon Tourtellot, Duell, Sloan and Pearce. New York.

Yates, W. V. 1873. The Civil Service English Grammar. Notes on the History and Grammar of the English Language. For the use of Civil Service Candidates, The Higher Classes in Public Schools, And Students in Training Colleges. Windermere Grammar School. London: Lockwood \& Co. 